\title{
Morphometric analysis using SRTM and GIS in synergy with depiction: a case study of the Karmanasa River basin, North central India
}

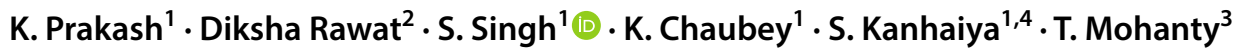

Received: 30 July 2018 / Accepted: 26 December 2018 / Published online: 4 January 2019

(c) The Author(s) 2019

\begin{abstract}
The Karmanasa basin is spread over the Kaimur sandstone (Upper Vindhyan) and marginal Ganga plain with the areal extension of about $7926 \mathrm{~km}^{2}$. The quantitative approach of the basin development of the Karmanasa River basin was carried out by the morphometric parameters. The drainage network was extracted from SRTM data. The trellis pattern characterizes upstream of the drainage basin, while the dendritic pattern is noticed in middle and downstream of the basin. The drainage density (0.34-0.44) indicates that the basin has highly permeable subsoil and thick vegetative cover. Relatively larger values of form factor (SW-1, SW-2, SW-3, SW-6 and KW) signify higher flow peak for a shorter duration. High values of ruggedness number and relief ratio suggest that Karmanasa basin is prone to soil erosion. The present work shows that the Karmanasa basin is less prone to flood, vulnerable to soil erosion and a good resource of surface water. This study would help to utilize the water resources and extended for sustainable development of the Karmanasa River basin area.
\end{abstract}

Keywords North central India $\cdot$ Karmanasa River basin $\cdot$ Morphometric $\cdot$ Drainage density $\cdot$ Soil erosion

\section{Introduction}

Morphometric analysis of the river basin is a quantitative representation of basin. Morphometric analysis of a basin provides information about the characteristics of the drainage system, topographic pattern of earth's surface, the shape and dimensions of its landforms, and it is also an imperative technique to assess and comprehend the role of basin dynamics (Pati et al. 2006, 2008; Withanage et al. 2014; Prakash et al. 2016a, b; Singh et al. 2018a, b). The morphometric analysis strengthens fundamental of the geometric uniqueness of the fluvial landscape with the degree of lithological and structural controls (Pophare and Balpande 2014). In addition, the drainage patterns have good indicators for

\section{S. Singh}

geosaurabh@gmail.com

1 Centre of Advanced Study in Geology, Institute of Science, Banaras Hindu University, Varanasi, India

2 Department of Applied Geology, IIT (ISM), Dhanbad, India

3 Civil Engineering Department, Ujjain Engineering College, Ujjain, India

4 Prof. Rajendra Singh (Rajju Bhaiya), Institute of Physical Sciences for Study and Research, VBSPU, Jaunpur, India subsurface geology and effective processes (Ritter 1986). The morphometric analysis was adopted to determine issues related to basin analysis (Thomas et al. 2010; Singh et al. 2014); prioritization of micro-basins provides valuable information water resources potential assessment and management (Chandrashekar et al. 2015; Pankaj and Kumar 2009; Sarmah et al.2012; Vandana 2013).

Digital elevation model (DEM) is the dataset for various studies that include morphometric, neo-tectonic and hydrologic studies (Jensen 1991; Patel et al. 2016; Wise 2000; Singh and Kanhaiya 2015; Prakash et al. 2017a, b, c; Kanhaiya et al. 2018). Extracting drainage parameters from DEM is proficient, accurate and efficient (Moore et al. 1991). GIS platform is ideal for morphometric analysis because of its potency in processing and quantifying topographic data (Altaf et al. 2013; Prakash et al. 2016a, b). In the absence of hydrologic data, morphometric analysis can provide significant information about hydrologic characteristics of the basin (Perucca and Angilieri 2011; Angillieri 2012; Soni 2016; Kabite and Gessesse 2018; Kaushik and Ghosh 2018a, b).

These studies tried to the developed relationship between morphometric drainage parameters and hydrologic characteristics of the basin using GIS technique. Therefore, the present aim of the study was to quantify morphometric

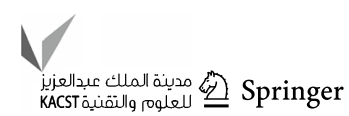


parameters (linear, areal and relief aspects) and hydrologically characterize the Karmanasa basin. This valuable information could help in soil and water resource planning and basin management.

\section{Study area}

The Karmanasa River is an important marginal plain tributary of Ganga River (Fig. 1). The Karmanasa originates at the height of 350 meters of the Kaimur Group of Upper Vindhyan Supergroup near Sarodag in Kaimur district of Bihar (Fig. 1). The river flows in a north-westerly direction through the marginal Ganga plain near Chandauli district (Uttar Pradesh), also it forms the eastern boundary between Uttar Pradesh and Bihar, and finally joins the Ganga river near Chausa district of Bihar. The total drainage area of the Karmanasa River basin is $7926 \mathrm{~km}^{2}$, and perimeter of the basin is $387 \mathrm{~km}$. Panoramic view of the Karmanasa River is shown in Fig. 2.

Its major tributaries are the Durgavati, the Chandraprabha, the Karunuti, the Nadi and the Khajuri. The Karmanasa River reaches the plains by a succession of leaps, including two falls known as the Devdari and the Chhanpathar.

\section{Methodology}

A number of studies revealed that Shuttle Radar Topography Mission Digital Elevation (SRTM-DEM) is much better than ASTER DEM in provided that relatively accurate data to morphometric analyses (Farr et al. 2007). SRTMDEM data are chosen to ASTER DEM due to its nailing vertical and horizontal accuracy (Sun et al. 2003; Forkuor and Maathuis 2012; Kaushik and Ghosh 2015a, b; Patel et al. 2016). In this study, missing data in SRTM-DEM
Fig. 1 Map showing the position of the Karmanasa River basin. 3D view (SRTM) of the study area shows Karmanasa River flowing between Ganga and Son River

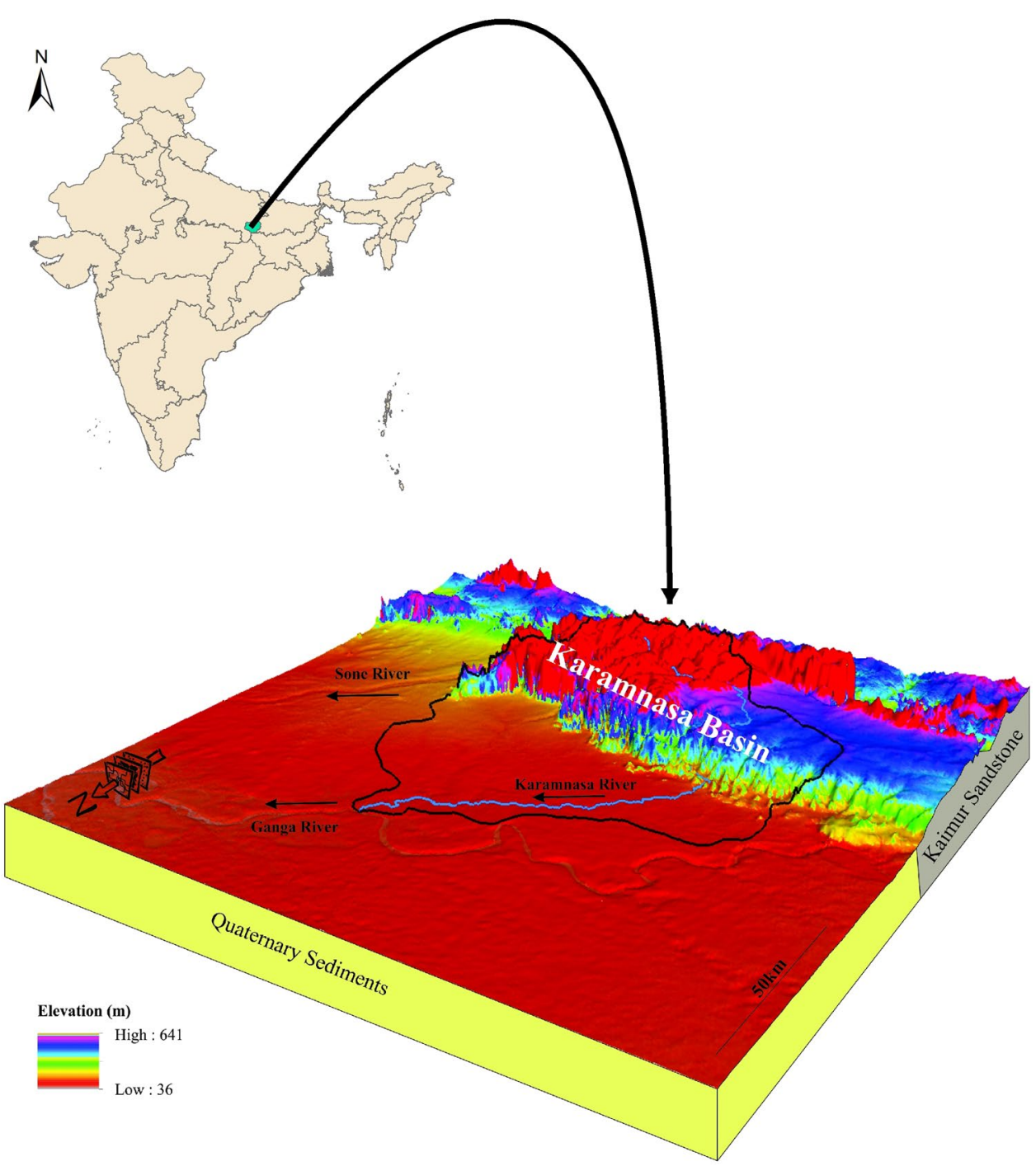


Fig. 2 a Panoramic view of the Karmanasa River is an exposition of meandering nature. $\mathbf{b}$ Incision of the river and development of cliff section along the right bank of Karmanasa River

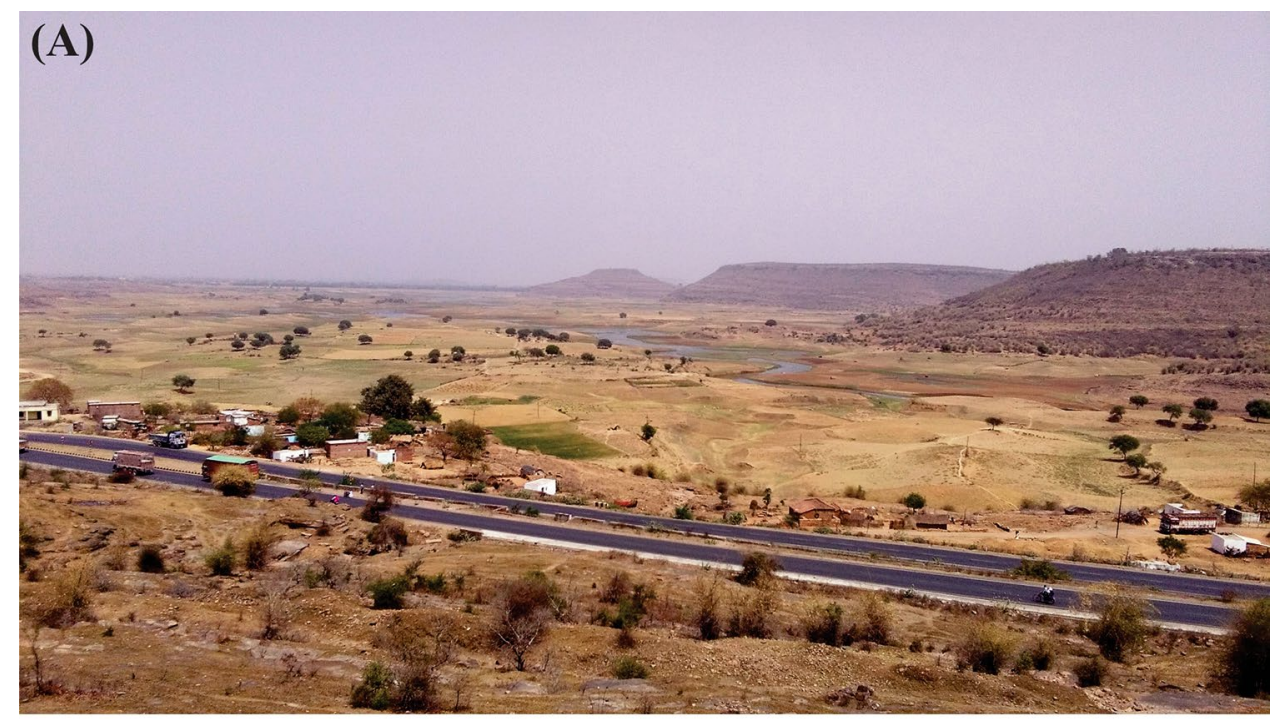

(B)

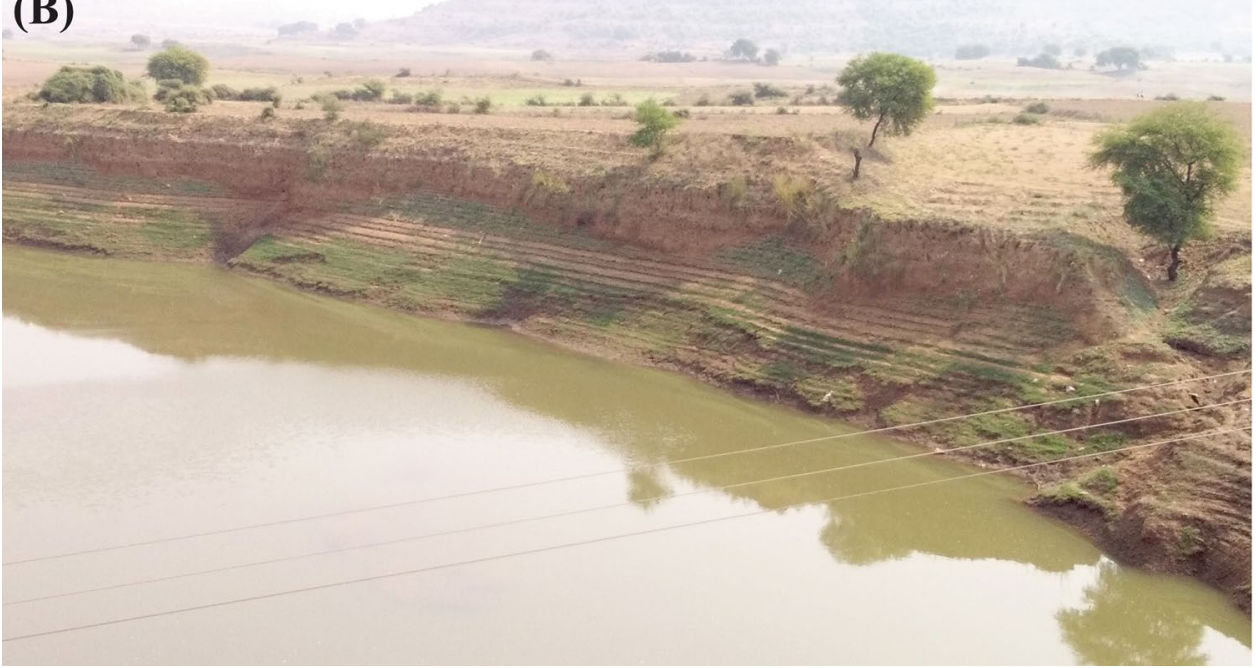

(Fig. 1) are filled by interpolation techniques and sink fill algorithm applied as preprocessing of DEM for minimizing errors.

The base maps of the basins were prepared from SRTM data and data to download from the Consultative Group for International Agriculture Research Consortium for Spatial Information (CGIAR-CSI). Drainage map is derived from the processing of an SRTM data of the study area, with a spatial resolution of $90 \mathrm{~m}$. ArcGIS-10 software was used for delineating the study area and exporting the information. Drainage network was analyzed using Horton's (1932, 1945), and Strahler (1964) methods were adopted. The morphometric parameter (length of the individual stream, basin area and perimeter of the basin) was extracted in the Arc GIS-10 platform and used for the morphometric analysis (linear, areal and relief aspects, Table 1). As a result, significant geomorphic parameters such as contours, slope gradient and aspects have been quantified.

\section{Results}

The morphometric analysis includes a mathematical analysis of the basin, altitude, volume, slope, profiles of the stream (Clark 1966). The Karmanasa basin occupies $7926.19 \mathrm{~km}^{2}$ areas in Kaimur sandstone and marginal Ganga plain. The parameters linear, areal and relief aspects have been examined and described in the following sections.

The drainage orientations of the Karmanasa River basin (KW) show polymodal distribution. The drainage patterns in the Karmanasa basin are dendritic in nature, reflecting that the significant parts of the basin have uniform lithology and horizontal to gently dipping strata, while the trellis drainage pattern also noticed in the marginal part of the basin (Fig. 3). The river is following the regional slope and is well adjusted to the different geological structures of the area. The dendritic drainage pattern indicates that the area has homogeneous lithology. 
Table 1 Mathematical formulae and their observed values of linear parameters

\begin{tabular}{llllllll}
\hline & SW-1 & SW-2 & SW-3 & SW-4 & SW-5 & SW-6 & KW \\
\hline Perimeter $(\mathrm{km})$ & 177.15 & 231 & 183.94 & 212.14 & 164.98 & 148.47 & 387.68 \\
Area $\left(\mathrm{km}^{2}\right)$ & 1291.69 & 1607.59 & 1480.12 & 1045.1 & 772.79 & 1061.13 & 7926.19 \\
Max. length of basin $\left(L_{\mathrm{b}}\right)(\mathrm{km})$ & 61.93 & 68.31 & 63.51 & 61.94 & 63.41 & 58.05 & 120.28 \\
Bifurcation ratio $\left(R_{\mathrm{b}}\right)$ & & & & & & & \\
$\quad N_{u} / N(u+1)$ (Horton 1945) & & & & & & & \\
1st/2nd order & 7.41 & 4.26 & 5.62 & 4.61 & 4.41 & 5.5 & 5.34 \\
2nd/3rd & 4 & 5.2 & 4 & 3.25 & 3 & 4.33 & 4.08 \\
3rd/4th & 3 & 5 & 1 & 4 & 4 & 3 & 4 \\
4th/5th & & & & & & & 3 \\
5th/6th & & & & & & & 2 \\
Average & 4.80 & 4.82 & 3.54 & 3.95 & 3.80 & 4.28 & 3.68 \\
Stream length ratio $\left(R_{\mathrm{l}}\right)$ & & & & & & & \\
$R_{\mathrm{l}}=L_{u} / L(u-1)($ Horton 1945) & & & & & & & \\
6th/5th order length & & & & & & & \\
5th/4th & & & & & & & 0.62 \\
4th/3rd & 0.1 & 1.78 & 0.39 & 3.52 & 1.61 & 0.2 & 0.71 \\
3rd/2nd & 1.56 & 0.52 & 0.53 & 3.58 & 0.3 & 0.96 & 0.64 \\
2nd/1st & 0.35 & 0.47 & 0.67 & 0.28 & 0.76 & 0.37 & 0.47 \\
Average & 0.67 & 0.92 & 0.53 & 2.46 & 0.89 & 0.51 & 0.52 \\
Rho coefficient $(\rho)$ (Horton 1945) & & & & & & & \\
$\rho=R_{\mathrm{l}} / R_{\mathrm{b}}$ & 0.13 & 0.19 & 0.14 & 0.62 & 0.23 & 0.11 & 0.14 \\
\hline
\end{tabular}

\section{Linear aspects}

The perimeter of the Karmanasa basin is $387.68 \mathrm{~km}$ (Table 2). According to Horton (1945), a measure of the position of the stream in the hierarchy of tributaries is defined as stream order. The classification of streams based on the stream order and tributary junction's type has demonstrated to be a convenient marker of stream size, discharge and drainage area (Strahler, 1957). The KW is allocated as 6th-order stream (Fig. 3).

Stream length is a significant morphometric parameter of the basin as it reveals surface runoff nature. Streams that have relatively smaller lengths are characteristics of the steeper slope and finer texture of the area. The streams having comparatively long lengths are suggestive of flat topography with gentle gradients. According to the law of stream length (Horton 1945), the total length of stream segments is maximum in first-order streams and decreases as the stream order increases. The mean and total stream length of each stream order is given in Table 2. The relationship between stream length and basin area is characterized as the headward erosion is the predominant driver for the drainage network development and expansion (Hack 1957). The average stream length ratio is observed maximum 2.46 (SW-4) and minimum 0.53 (SW-3) (Table 2), suggestive of the control of rock types and structures in the development of drainage basin.
Bifurcation ratio (Strahler 1964) is defined as the ratio of the number of streams of a given order $\left(N_{u}\right)$ to the number of streams to the next higher order $\left(N_{u}+1\right)$. The average values of bifurcation ratio that vary from 3.54 (SW-3) to 4.82 (SW2) suggest the structures control of the basin.

\section{Areal aspects}

Drainage density $\left(D_{\mathrm{d}}\right)$ is described as the ratio of total channel lengths to the basin area (Horton 1945; Strahler 1964). The $D_{\mathrm{d}}$ in the study area varies between $0.34(\mathrm{SW}-2)$ and 0.44 (SW-6) (Table 2).

The drainage texture refers to the relative channel spacing of a total number of stream segments of a given length per unit area (Smith 1950), which is notably prejudiced by climate, vegetation, lithology, soil type, relief and stage of development of a basin.

According to Smith (1950), the drainage texture is classified into five different textures, very coarse $(<2)$, coarse (2-4), moderate (4-6), fine (6-8) and very fine $(>8)$. The study area comes under very coarse drainage texture (0.02-0.03; Table 2). According to Schumm (1956), inverse of drainage density is termed as a constant of channel maintenance $(C)$. In the study area, $C$ varies from 2.27 to 2.94 (Table 2). A significant value of $C$ indicates a higher infiltration rate and matures to the old stage of the river basin (Schumm 1956). The length of overland 


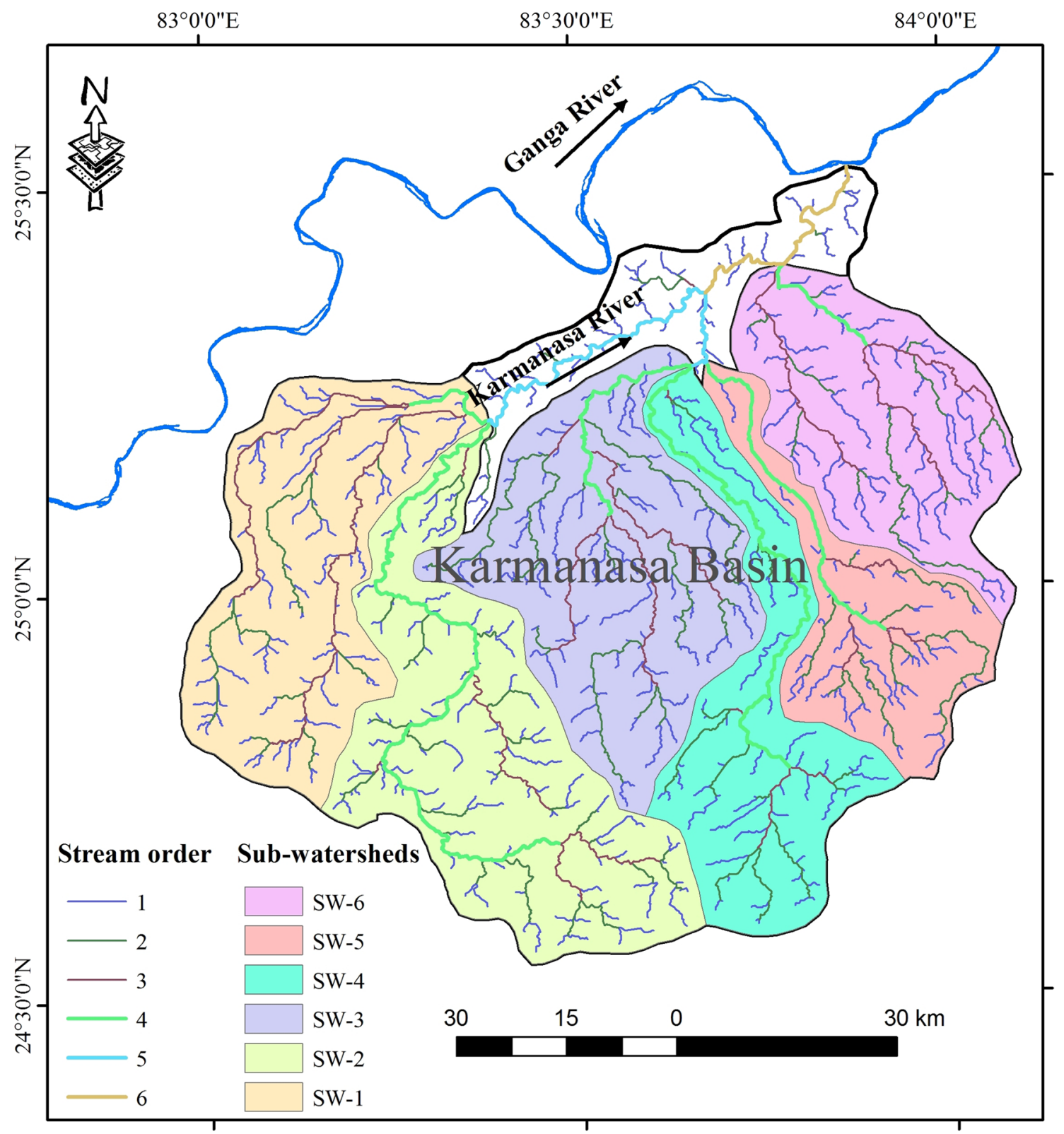

Fig. 3 The drainage of the Karmanasa River basin with six sub-basins

flow $\left(L_{\mathrm{g}}\right)$ is the length of runoff over the ground before it gets submerged into the main stream (Horton (1945). The value of $L_{\mathrm{g}}$ is affected by rainfall intensity, infiltration rate, soils, vegetations covers, etc. In the study area, $L_{\mathrm{g}}$ is varied from 1.13 to 1.47 (Table 2). The form factor is used to predict the flow intensity in the basin (Horton 1945; Gregory and Walling 1973). Form factor shows the inverse relationship with the square of the axial length and a direct relationship with peak discharge (Magesh et al. 2012). FF of KW is 0.54 (Table 2). According to Millar (1958), the circulatory ratio $\left(R_{\mathrm{c}}\right)$ is defined as the ratio of basin area to the area of a circle having the same perimeter as the basin.
The basin has circularity ratios that range from 0.4 to 0.7 to be strongly elongated and highly permeable homogenous lithology (Miller and Summerson 1960). $R_{\mathrm{c}}$ of KW is 0.66, and other sub-basin gave in Table 2. Elongation ratio $\left(R_{\mathrm{e}}\right)$ is defined as the ratio of the diameter of a circle of the same area as the basin to a maximum basin length (Schumm 1956). $R_{\mathrm{e}}$ ratio varies between 0.40 and 1.0 over a sufficient diversity of geology and climate. $R_{\mathrm{e}}$ values close to 1.0 are characterized by very low relief, whereas values in the range of $0.6-0.8$ are generally associated with strong relief and steep ground slope. $R_{\mathrm{e}}$ of basin and sub-basin varies from 0.49 to 0.83 (Table 2). 
Table 2 Mathematical formulae and the calculated value of areal and relief parameters

\begin{tabular}{|c|c|c|c|c|c|c|c|c|c|}
\hline & \multirow[t]{2}{*}{ Mathematical formula } & \multirow[t]{2}{*}{ References } & \multicolumn{7}{|c|}{ Observed values } \\
\hline & & & $\mathrm{W}-1$ & SW-2 & SW-3 & SW-4 & SW-5 & SW-6 & KW \\
\hline \multicolumn{10}{|l|}{ Areal aspect } \\
\hline Drainage density $\left(D_{\mathrm{d}}\right)$ & $\begin{array}{l}D_{\mathrm{d}}=L / A ; \text { where } L \text { total length of } \\
\text { streams; } A \text { area of watershed }\end{array}$ & Horton (1945) & 0.4 & 0.34 & 0.41 & 0.37 & 0.42 & 0.44 & 0.39 \\
\hline Stream frequency $\left(F_{\mathrm{s}}\right)$ & $\begin{array}{l}F_{\mathrm{s}}=N / A ; \text { where } N \text { total number } \\
\text { of streams; } A \text { area of watershed }\end{array}$ & Horton (1945) & 0.08 & 0.08 & 0.07 & 0.07 & 0.09 & 0.08 & 0.08 \\
\hline Drainage texture $(T)$ & $\begin{array}{c}T=F_{\mathrm{s}} * D_{\mathrm{d}} ; \text { where } F_{\mathrm{s}} \text { stream fre- } \\
\text { quency; } D_{\mathrm{d}} \text { drainage density }\end{array}$ & Horton (1945) & 0.032 & 0.02 & 0.02 & 0.02 & 0.03 & 0.03 & 0.03 \\
\hline Length of overland flow $\left(L_{\mathrm{g}}\right)$ & $\begin{array}{l}L_{\mathrm{g}}=1 / 2 D_{\mathrm{d}} ; \text { where } D_{\mathrm{d}} \text { drainage } \\
\text { density }\end{array}$ & Horton (1945) & 1.25 & 1.47 & 1.21 & 1.35 & 1.19 & 1.13 & 1.28 \\
\hline $\begin{array}{l}\text { Constant of channel mainte- } \\
\text { nance }\end{array}$ & $\begin{array}{l}C=1 / D_{\mathrm{d}} ; \text { where } D_{\mathrm{d}} \text { drainage } \\
\text { density }\end{array}$ & Horton (1945) & 2.5 & 2.94 & 2.43 & 2.75 & 2.38 & 2.27 & 2.56 \\
\hline Form factor & $\begin{array}{c}R_{\mathrm{f}}=A /\left(L_{\mathrm{b}}\right)^{2} ; \text { where } A \text { area of } \\
\text { watershed; } L_{\mathrm{b}} \text { basin length }\end{array}$ & Horton (1945) & 0.33 & 0.34 & 0.36 & 0.27 & 0.19 & 0.31 & 0.54 \\
\hline Circulatory ratio $\left(R_{\mathrm{c}}\right)$ & $\begin{array}{l}R_{\mathrm{c}}=4 p A / P^{2} ; \text { where } P \text { is perim- } \\
\text { eter of basin }\end{array}$ & Miller (1953) & 0.014 & 0.37 & 0.54 & 0.29 & 0.35 & 0.6 & 0.66 \\
\hline Elongation ratio $\left(R_{\mathrm{e}}\right)$ & $\begin{array}{l}R_{\mathrm{e}}=2 \sqrt{ }(A / \pi) / L_{\mathrm{b}} ; \text { where } A \text { area } \\
\quad \text { of basin; } L_{\mathrm{b}} \text { basin length; } \\
\quad \pi=3.14\end{array}$ & Schumm (1956) & 0.65 & 0.66 & 0.68 & 0.58 & 0.49 & 0.63 & 0.83 \\
\hline Shape index $\left(S_{\mathrm{w}}\right)$ & $S_{\mathrm{w}}=1 / F_{\mathrm{s}}$ & Horton (1932) & 3.03 & 2.94 & 2.77 & 3.7 & 5.26 & 3.22 & 1.85 \\
\hline \multicolumn{10}{|l|}{ Relief aspect } \\
\hline Basin relief $(R)(\mathrm{km})$ & $\begin{array}{l}\text { Vertical distance between the } \\
\text { lowest and highest points of } \\
\text { watershed }\end{array}$ & Schumm (1956) & 0.304 & 0.56 & 0.41 & 0.57 & 0.42 & 0.085 & 0.58 \\
\hline Relief ratio $\left(R_{\mathrm{r}}\right)$ & $\begin{array}{l}R_{\mathrm{r}}=R / L_{\mathrm{b}} ; \text { where } R \text { basin relief; } \\
L_{\mathrm{b}} \text { basin length }\end{array}$ & Schumm (1956) & 0.004 & 0.008 & 0.006 & 0.009 & 0.006 & 0.014 & 0.004 \\
\hline Ruggedness number & $\begin{array}{l}R_{\mathrm{n}}=B_{\mathrm{h}} \times D_{\mathrm{d}} \text {; where } R \text { basin } \\
\quad \text { relief; } D_{\mathrm{d}} \text { drainage density }\end{array}$ & Schumm (1956) & 0.12 & 0.19 & 0.16 & 0.21 & 0.17 & 0.037 & 0.22 \\
\hline Gradient ratio & $\begin{array}{l}R_{\mathrm{g}}=E_{\mathrm{s}}-E_{\mathrm{m}} / L_{\mathrm{b}} ; E_{\mathrm{s}} \text { is the eleva- } \\
\text { tion at the source, } E_{\mathrm{m}} \text { is the } \\
\text { elevation at the mouth }\end{array}$ & Sreedevi et al. (2009) & 0.003 & 0.006 & 0.005 & 0.007 & 0.004 & 0.008 & 0.004 \\
\hline Melton ruggedness ratio $\left(\mathrm{MR}_{\mathrm{n}}\right)$ & $\mathrm{MR}_{\mathrm{n}}=R / \mathrm{A}^{1 / 2}$ & Melton (1965) & 0.008 & 0.013 & 0.011 & 0.01 & 0.015 & 0.002 & 0.006 \\
\hline
\end{tabular}

\section{Relief aspects}

In the relief, aspects are calculated as relief ratio $\left(R_{\mathrm{r}}\right)$, basin relief $(R)$, ruggedness number $\left(R_{\mathrm{n}}\right)$ and gradient ratio $\left(R_{\mathrm{g}}\right)$, and the data are presented in Table 2. Basin relief is a parameter that shows the elevation difference between the highest and lowest point in the basin (Hadley and Schumm 1961). It is the determined stream gradient that influences flood pattern and volume of sediment that can be transported (Hadley and Schumm 1961; Kanhaiya et al. 2018). The basin relief varies from 0.085 to $0.58 \mathrm{~km}$ (Table 2). According to Schumm (1956), relief ratio is a ratio between basin relief and basin length. Relief ratio is an effective measure of gradient aspects of the basin (Schumm 1956; Vittala et al. 2004). Relief ratio in study area varies from 0.004 (KW) and 0.014 (SW-6) (Table 2). The ruggedness number (Strahler 1958; Vijith and Satheesh 2006) is defined as the product of basin relief and drainage density. The ruggedness value of the Karmanasa basin is 0.22 (Table 2). Gradient ratio is a parameter which indicates channel slope which enables measurement of the runoff volume (Sreedevi et al. 2004, 2009; Thomas et al. 2010). The $R_{\mathrm{g}}$ value of $\mathrm{KW}$ is 0.004 (Table 2).

\section{Hydro-geomorphologic characteristics of Karmanasa River basin}

The basin morphometric parameters are strongly correlated with basin hydrologic processes (Jensen 1991; Altaf et al. 2013; Prakash et al. 2017a, b; Kanhaiya et al. 2018; Singh et al. 2018a, b; Kabite and Gessesse 2018; Kaushik and Ghosh 2018a, b). The morphometric analyses make it possible to infer the significant hydrologic behavior of a basin such as flooding, soil erosion and groundwater recharge of a basin from the quantitative morphometric analysis. 


\section{Flood status of the basin}

The flooding condition of a Karmanasa basin and subbasin could be incidental from morphometric parameters like area, basin length, drainage density, drainage frequency, form factor, circularity ratio and elongation ratio. Elongated sub-basins (SW-1, SW-2, SW-3, SW-4, SW-5, SW-6) (Fig. 4), poor drainage density and low frequency of the river basin are predictable to generate minimum peak runoff (Miller 1953; Strahler 1964; Singh and
Singh 1997; Soni 2016). The Rho coefficent is a significant parameter linking drainage density to physiographic development of basin and indicates storage capacity of drainage network (Horton 1945). The higher values of Rho coefficient for SW-4 and SW-5 (0.23 \& 0.62$)$ has indicated the advanced hydrologic storage during the peak discharge and for SW-1, SW-2, SW-3, SW-6, and KW the Rho value infer the low hydrologic storage during the flood. The low value of Rho coefficient indicates the risk
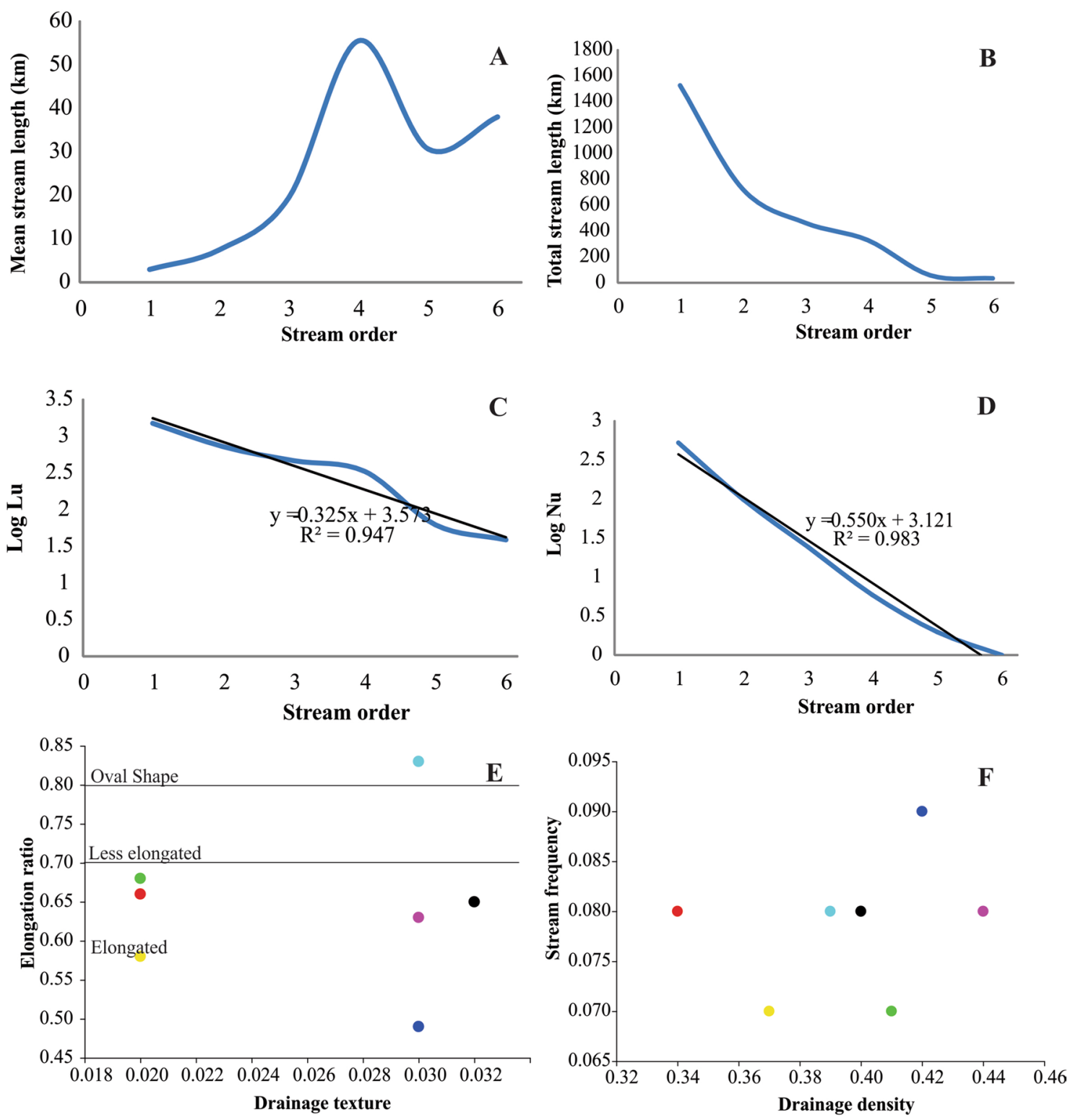

SW-1 Osw-2 Osw-3 Osw-4 Osw-5 Osw-6 OKW

Fig. 4 Bivariate plots of a mean stream length versus stream order, b total stream length versus stream order, c stream length $\left(L_{u}\right)$ versus stream order $\left(N_{u}\right), \mathbf{d} \log N_{u}$ versus stream order $\left(N_{u}\right)$ (Horton's first law) and $\mathbf{b}$ stream length $\left(L_{u}\right)$ versus stream number, e elongation ratio versus drainage texture, all sub-basins are elongated in shape but Karmanasa basin in oval shape, $\mathbf{f}$ stream frequency versus drainage texture 
of flooding during heavy rainfall as the drainage channels have less capacity to store much runoff.

The form factor is prophesying the flow concentration of a basin with a defined area and also has a direct linkage to peak discharge (Horton 1945; Gregory and Walling 1973). Relatively larger values of $F_{\mathrm{f}}$ (SW-1, SW-2, SW-3, SW-6, $\mathrm{KW}$ ) indicate higher flow peak for a shorter duration. The value of the $F_{\mathrm{f}}$ indicates that the interval time is high in the area resulting in less chance for flooding to occur.

\section{Soil erosion characteristics of the basin}

Soil erosion potential and its intensity in a given basin could be obtained from areal and relief aspect (Tejpal 2013). The parameters indicate soil erosion potential which is the length of overland flow $\left(L_{\mathrm{g}}\right)$, Constant of channel maintenance $(C)$, basin relief, relief ratio, channel gradients, ruggedness number, basin length and Melton ruggedness number. A high values of $L_{\mathrm{g}}(1.35-1.47)$ and $C(0.60-0.66)$ for SW-1, SW-2, SW-3, SW-4, SW-5, SW-6, and KW, indicate that the area has undergone through the sheet erosion process (Horton 1945; Strahler 1952; Schumm 1956).

The variability in stream length ratio (RI) shows the relationship between slope and topography. It has an essential control of discharge and different erosional stages of the basin (Sreedevi et al. 2004). The increase in RI value from lower to higher order illustrates geomorphic maturity of the basin (Thomas et al. 2010). The high stream length ratio (2.46) is alluding high erosional activity in the subwatershed (SW-4).

The parameters $\left(L_{\mathrm{g}}, C, R, R_{\mathrm{n}}, \mathrm{RI}\right)$ evince that the basin is characterized by a steep slope and rough topographically which allows sediment production and transportation (Wilford et al. 2004). The ruggedness value (0.22) of the Karmanasa basin refers that the region is more prone to soil erosion. More elongated basin configuration (SW-1, SW-2, SW-3, SW-4, SW-5, SW-6) and drainage characteristics (low drainage density, coarse texture and low drainage frequency) of the sub-basins (SW-1, SW-2, SW-3, SW-4, SW-5, SW-6) may counterbalance the high soil erosion status that could result from topographic effect. The vulnerability of the basin to severe soil erosion could be tailored by vegetation cover and soil type.

\section{Groundwater recharges potential of the basin}

Groundwater recharge potential is prejudiced by stream frequency, drainage density, drainage texture, length of overland flow, etc. Those parameters represent information about the infiltration capacity of the surface and surface runoff (Singh et al. 2014; Soni 2016). Low drainage density of the sub-basins (SW-1, SW-2, SW-3, SW-4, SW-5, SW-6) is favoured of highly permeable subsoil materials or resistant lithology, under dense vegetations (Strahler 1964). According to this study, sub-basins (SW-1, SW-2, SW-3, SW-4, SW-5, SW-6) show high groundwater recharges potential.

Morphometric parameters (stream frequency, drainage density, drainage texture, length of overland flow) indicate that water runoff and sediments transportation are slow in the study area which gets extended time to infiltrate during such slow motion. This runoff could be due to the occurrence of underlying permeable materials. Karmanasa basin has been six-order basin. The drainage density of the subbasin and Karmanasa basin indicates that the nature of subsurface materials is permeable as the drainage density is less than 0.5. Poor drainage density and coarse drainage texture characteristic of the Karmanasa basin show good potential for the construction of artificial recharge structures. The mean bifurcation ratios in the study area are between 3.8 and 4.82, demonstrating that the stream networks are formed in the least structural disturbances (Chow 1964; Mekel 1970; Nautiyal 1994; Thomas et al. 2010; Kanhaiya et al. 2018).

\section{Conclusion}

The study remote sensing and GIS techniques are useful tools to substantiate the different stages of hydro-geomorphologic interpretation of river basin. Morphometric analyses bestow way to understand the status of landform and their processes. High values of ruggedness number and relief ratio suggest that Karmanasa basin is prone to soil erosion with the high degree of slopes and high surface runoff. The analysis is further supported for water recourse planning and management in the water sacristy area of the basin. The various attributes of a drainage basin play a significant role in locating sites for artificial recharge structures. However, a comparison of all the six sub-basins shows that the poor drainage density hence is suitable for construction of recharge structures. In the study area, streams up to the 3 rd order are traversed in high altitude, whereas higherorder (4th, 5th and 6th order) streams flow in the relatively flat area and thus will be suitable for the construction of small storage dam (check dams) in the area to recharge the groundwater and further to improve the water table in the Karmanasa basin.

Acknowledgements KP is thankful to DST-SERB Project (No. $\mathrm{P} 07 / 673$ ) for the financial assistant. The authors are also grateful to the Head of Department, Geology, Banaras Hindu University, for providing departmental GIS laboratory for computing facilities.

Open Access This article is distributed under the terms of the Creative Commons Attribution 4.0 International License (http://creativeco mmons.org/licenses/by/4.0/), which permits unrestricted use, distribution, and reproduction in any medium, provided you give appropriate credit to the original author(s) and the source, provide a link to the Creative Commons license, and indicate if changes were made. 


\section{References}

Altaf F, Meraj G, Romshoo AS (2013) Morphometric analysis to infer the hydrological behaviour of Lidder Watershed, Western Himalaya, India. Geography J 2013:1-14

Angillieri EYM (2012) Morphometric characterization of the Carrizal basin applied to the evaluation of flash floods hazards, San Juan, Argentina. Quat Int 253:74-79

Chandrashekar H, Lokesh VK, Sameena M, Roopa J, Ranganna G (2015) GIS based morphometric analysis of two reservoir catchments of Arkavati River, Ramanagaram District, Karnataka. International Conference on water resources, Coastal and Ocean Engineering (ICWCOE2015). Aquat Procedia 4:1345-1353

Clark C (1966) Morphometry from maps. Essay in geomorphology. Elsevier publication company, New York, pp 235-274

Chow VT (1964) Handbook of applied hydrology. McGraw-Hill, New York

Farr T, Rosen PA, Caro E, Crippen R, Duren R, Hensley S (2007) The shuttle radar topography mission. Rev Geophys 45:RG2004

Forkuor G, Maathuis B (2012) Chapter 9: Comparison of SRTM and ASTER derived digital elevation models over two regions in Ghana-implications for hydrological and environmental modeling. In: Piacentini T (ed) Studies on environmental and applied geomorphology. InTech, Rijeka, pp 219-240

Gregory KJ, Walling DE (1973) Drainage basin. Form and process: A geomorphological approach. Edward Arnold, London

Hack JT (1957) Studies of longitudinal stream profiles in Virginia and Maryland. US Geological Survey Professional paper 294-B Horton, R.E. (1932)

Hadley R, Schumm S (1961) Sediment sources and drainage basin characteristics in upper Cheyenne River basin. USGS water supply paper, 1531-B Washington DC, 198

Horton RE (1932) Drainage basin characteristics. Trans Am Geophys Union 13:350-361

Horton RE (1945) Erosional development of streams and their drainage basins hydrophysical approach to quantitative morphology. Geol Soc Am Bull 56:275-370

Jensen SK (1991) Applications of hydrologic information automatically extracted from digital elevation models. Hydrol Process $5(1): 31-44$

Kabite G, Gessesse B (2018) Hydro-geomorphological characterization of Dhidhessa River Basin, Ethiopia. Int Soil Water Conserv Res 6:175-183

Kanhaiya S, Singh BP, Singh S, Mittal P, Srivastava VK (2018) Morphometric analysis, bed-load sediments and weathering intensity in the Khurar River Basin, Central India. Geol J. https ://doi.org/10.1002/gj.3194

Kaushik P, Ghosh P (2015a) 3D DEM delineation of Chambal river basin from SRTM data using remote sensing and GIS technology. Int J Remote Sens Geosci 4(4):1-6

Kaushik P, Ghosh P (2015b) Geomorphic evolution of Chambal River origin in Madhya Pradesh using remote sensing and GIS. Int J Adv Remote Sens GIS 4(1):1130-1141

Kaushik P, Ghosh P (2018a) Morphometric analysis of Shipra River sub-basin, India, remote sensing and GIS approach. Int J Creat Res Thoughts 6(1):1536-1546

Kaushik P, Ghosh P (2018b) Morphometric analysis of Mej subbasin, Rajasthan, India, using remote sensing and GIS applications. Int J Creat Res Thoughts 6(1):1379-1392

Magesh NS, Jitheshlal KV, Chandrasekar N, Jini KV (2012) GISbased morphometric evaluation of Chimmini and Mupily watersheds, parts of Western Ghats, Thrissur District, Kerala, India. Earth Sci Inf 5:111-121

Mekel JFM (1970) The use of aerial photographs in geological mapping. ITC Text Book Photo-interpret 8:1-169
Melton MA (1965) The geomorphic and paleo-climatic significance of alluvial deposits in Southern Arizona. J Geol 73:1-3

Millar JP (1958) High mountainous streams; effect of geology on channel characteristics and bed material. New Mexico Bureau Mines Miner Resour 4:51

Miller VC (1953) A quantitative geomorphic study of drainage basin characteristics in the Clinch mountain area, Virginia and Tennessee. Department of Geology, Columbia University, New York, pp 389-402

Miller OM, Summerson CH (1960) Slope zone map. Geogr Rev 50:194-202

Moore ID, Grayson RB, Ladspm AR (1991) Digital terrain modelling: a review of hydrological, geomorphological and biological applications. Hydrol Process 5:3-30

Nautiyal MD (1994) Morphometric analysis of a drainage basin, district Dehradun, Uttar Pradesh. J Indian Soc Remote Sens 22(4):251-261

Pankaj A, Kumar P (2009) GIS-based Morphometric Analysis of five major-watersheds of Song river, Dehradun District, Uttarakhand with special reference to landslide incidences. J Indian Soc Remote Sens 37:157-166

Patel A, Katiyar KS, Prasad V (2016) Performances evaluation of different open source DEM using differential global positioning system (DGPS). Egypt J Remote Sens Space Sci 19(1):7-16

Pati JK, Malviya VP, Prakash K (2006) Basement re-activation and its relation to neotectonic activity in and around Allahabad, Ganga Plain. J Indian Soc Remote Sens 34:47-56

Pati JK, Lal J, Prakash K, Bhusan R (2008) Spatiotemporal shift of Western bank of the Ganga River, Allahabad City and its Implications. J Indian Soc Remote Sens 36:289-297

Perucca PL, Angilieri EY (2011) Morphometric characterization of Del Molle basin applied to the evaluation of flash floods hazard, Iglesia Department, San Juan, Argentina. Quatern Int 233:81-86

Pophare AM, Balpande US (2014) Morphometric analysis of Suketi river basin, Himachal Himalaya, India. J Earth Syst Sci 123:1501-1515

Prakash K, Mohanty T, Singh S, Chaubey K, Prakash P (2016a) Drainage morphometry of the Dhasan river basin, Bundelkhand craton, central India using remote sensing and GIS techniques. J Geomat 10:21-132

Prakash K, Singh S, Shukla UK (2016b) Morphometric changes of the Varuna river basin, Varanasi district, Uttar Pradesh. J Geom 10:48-54

Prakash K, Chaubey K, Singh S, Mohanty T, Singh CK (2017a) Morphometric analysis of the Satna river basin, Central India. Indian J Geomorphol 22:41-60

Prakash K, Mohanty T, Pati JK, Singh S, Chaubey K (2017b) Morphotectonics of the Jamini River basin, Bundelkhand Craton, Central India; using remote sensing and GIS technique. Appl Water Sci 7:3767-3782

Prakash K, Singh S, Mohanty T, Chaubey K, Singh CK (2017c) Morphometric assessment of Gomati river basin, middle Ganga plain, Uttar Pradesh, North India. Spat Inf Res 25:449-458

Ritter DF (1986) Process geomorphology, 2nd edn. William C. Brown Company Publishers, Dubuque

Sarmah K, Jha LK, Tiwari BK (2012) Morphometric analysis of a highland micro watershed in East Khasi Hills District of Meghalaya, India: using remote sensing and geographic information system (GIS) techniques. J Geol Reg Plan 5:142-150

Schumm SA (1956) Evolution of drainage systems and slopes in badlands at Perth Amboy, New Jersey. Geol Soc Am Bull 67:597-646

Singh S, Kanhaiya S (2015) Morphometry of the Barakar river basin, India: a remote sensing and GIS approach. Int J Curr Res 7(7):17948-17955

Singh S, Singh MC (1997) Morphometric analysis of Kanhar river basin. Natl Geogr J India 43(1):31-43

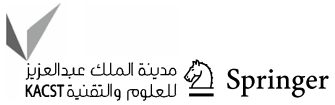


Singh P, Gupta A, Singh M (2014) Hydrological inferences from the watershed analysis of water resource management using remote sensing and techniques. Egypt J Remote Sens Space Sci 17:111-121

Singh S, Kanhaiya S, Singh A, Chaubey K (2018a) Drainage network characteristics of the Ghaghghar River Basin (GRB), Son Valley, India. Geol Ecol Landsc. https://doi.org/10.1080/24749 508.2018.1525670

Singh S, Kumar S, Mittal P, Kanhaiya S, Prakash P, Kumar R (2018b) Drainage basin parameters of Bagh river, a sub-basin of Narmada river, Central India: analysis and implications. J Appl Geochem 20(1):91-102

Smith KG (1950) Standards for grading textures of erosional topography. Am J Sci 248:655-668

Soni S (2016) Assessment of morphometric characteristics of Chakra watershed in Madhya Pradesh India using the geospatial technique. Appl Water Sci 7:2089-2102

Sreedevi PD, Subrahmanyam K, Ahmed S (2004) The significance of morphometric analysis for obtaining groundwater potential zones in a structurally controlled terrain. Environ Geol 47:412-420

Sreedevi PD, Owais S, Khan H, Ahmed S (2009) Morphometric analysis of a watershed of South India using SRTM data and GIS. J Geol Soc India 73:543-552

Strahler AN (1952) Hypsometric area altitude. Analysis of erosional topography. Geol Soc Am Bull 63:1117-1142

Strahler AN (1957) Quantitative analysis of watershed geomorphology. Trans Am Geophys Union 38:913-920

Strahler AN (1958) Dimensional analysis applied to fluvially eroded landforms. Geol Soc Am Bull 69:279-300

Strahler A (1964) Quantitative geomorphology of drainage basins and channel networks. In: Chow V (ed) Handbook of applied hydrology. McGraw Hill, New York, pp 439-476

Sun G, Ranson KJ, Kharuk VI, Kovacs K (2003) Validation of surface height from shuttle radar topography mission using shuttle laser altimeter. Remote Sens Environ 88(4):401-411
Tejpal (2013) Relief analysis of the tangri watershed in the lower shivalik and piedmont zone of Haryana and Punjab. Indian J Spat Sci 4(1):9-20

Thomas J, Joseph S, Thrivikramaji KP (2010) Morphometric aspects of a small tropical mountain river system, the southern Western Ghats, India. Int J Digit Earth 3:135-156

Vandana M (2013) Morphometric analysis and watershed prioritization: a case study of Kabani river basin, Wayanad district, Kerala, India. Indian J Geo-Mar Sci 42:211-222

Vijith H, Satheesh R (2006) GIS-based morphometric analysis of two major upland sub-watersheds of Meenachil river in Kerala. J Indian Soc Remote Sens 34:181-185

Vittala SS, Govindiah S, Honne Gowda H (2004) Morphometric analysis of sub-watersheds in the Pavagada area of Tumkur district, South India, using remote sensing and GIS techniques. J Indian Soc Remote Sens 32:351-362

Wilford DJ, Sakals ME, Innes JL, Sidle RC, Bergerud WE (2004) Recognition of debris flow, debris flood and flood hazard through watershed morphometrics. Landslides 1:61-66

Wise S (2000) Assessing the quality for hydrological applications of digital elevation models derived from contours. Hydrol Process 14(11-12):1909-1929

Withanage W, Dayawansa NDK, De Silva RP (2014) Morphometric analysis of the Gal Oya river basin using spatial data derived from GIS. Trop Agric Res 26:175-188

Publisher's Note Springer Nature remains neutral with regard to jurisdictional claims in published maps and institutional affiliations. 